\title{
Effect of Yoni Prakshalanam With Triphala Kashayam And Yoni Pichu With Jatyadi Tailam In Anti Sperm Anti Bodies (Asab) - A Case Study
}

\author{
Dr Maganti Anuradha
}

\author{
Sri Jayendra Saraswathi Ayurveda College and Hospital, Nazarathpettai, Thiruvallur (dt), \\ CHENNAI, Opp to Panimalar Engineering College 600123 India
}

\begin{abstract}
Infertility is a multi factorial condition. Immunological factor is one among the many factors responsible for infertility which is encountered in 5\% cases. Presence of antisperm antibodies is both male and female immunological factor. In females, cervical mucus may produce antibodies to the sperm which may affect fertility by either sperm immobilization or sperm agglutination. If ASAB are found in cervical mucus, the couple is advised to use condom or a diaphragm as a barrier method for 3 months. During this period, the antibodies gradually disappear and once the mucus is found to be normal, conception is attempted. The presence of serum antibodies has a bad prognosis and IVF \& GIFT technique is offered. The present article is a case presentation of the presence of ASAB in the serum of female partner. In this study treatment is given following Ayurvedic principles and the results are found to be encouraging. Yoni prakshalanam with Triphala Kashayam and Yoni Pichu with Jatyadi tailam reduced Serum ASAB. The yogas that are used have drugs that contain krimihara property. In general when an infection occurs, body produces antibodies to fight the infection. Here antibodies are produced against sperm considering them as foreign bodies. This aspect is taken as a main point and drugs containing krimihara property are used and it found to be successful.
\end{abstract}

Key words: Infertility, Immunological factor, antisperm antibodies, cervical factor, triphala kashayam, jatyadi tailam

\section{INTRODUCTION}

The antibodies in males are produced following infection (orchitis), trauma or vasectomy. Most common cause of antisperm antibodies is IgG, IgM \& IgA isotypes. IgG may be found in cervical mucus, serum and semen. IgA are found in cervical mucus and seminal plasma. IgM molecules are found exclusively in serum. The immunoglobulins can bind different parts of the sperm and make them immobile. Sperm agglutination tests, immobilization tests and immunoglobulin specific assays are available to detect immunological defects in the semen.If an immunological factor is suspected, the patient's serum and cervical mucus can be examined for the presence of ASAB. This is the case study of ASAB in the female partner.

\section{Patient Profile}

A female patient age - 30 years; marital life - 15 years; periods regular; serum ASAB - 54.77U/ml (Normal range $-<20 \mathrm{U} / \mathrm{ml})$.

Investigations like USG abdomen, follicular study of the patient and semen analysis of her husband were normal. All the routine investigations were normal.

In the present study, ASAB was considered as the female factor and treatment was done initially to know the efficacy of Ayurvedic treatment and the results were found to be encouraging. 
Dr Maganti Anuradha*, International Journal of Ayurvedic \& Herbal Medicine 8(3) May.-June. 2018 (3253-3255)

\section{MATERIALS AND METHODS}

\section{Materials:}

1. Internal medicines:

a) Sukumaram kashayam

b) Chandra prabhavati

c) Jeerakadyarishtam

\section{External medicines:}

a) Triphala kashayam

b) Jatyadi tailam

\section{Methods}

1. Yoni prakshalanam for 7 days for 3 consecutive cycles starting from $5^{\text {th }}$ day of cycle

2. Yoni pichu for 7 days for 3 consecutive cycles starting from $5^{\text {th }}$ day of cycle

\section{OBSERVATIONS AND RESULTS}

- After 3 consecutive cycles of treatment with Triphala kashaya yoni prakshalanam and Jatyadi Taila yoni pichu along with internal medicines, the patient was again tested for Serum ASAB and the result was $\mathbf{1 0 U} / \mathbf{m l}$ which is normal (Normal range $:<20 \mathrm{U} / \mathrm{ml}$ ).

\section{DISCUSSION}

As per Ayurvedic classics, there is no direct reference for Anti Sperm Anti Bodies.It is an immunological factor and antibodies to the sperm are produced either from male or cervical mucus of the female partner.Generally, whenever there is any infection in the body, antibodies are produced by the body as a defensive mechanism.Hence, either antibiotics or a drug which reduces the infection will be given.In the present case of $\mathrm{ASAB}$, it was taken that the cervical mucus of the female partner might have considered sperms as foreign bodies and as a result antibodies might have been produced against sperms.According to the principles of Ayurveda, these foreign bodies are considered as krimi and the line of treatment was planned accordingly and the results also are found to be encouraging.Most of the drugs that are used have krimihara property. For ex: Jatyadi tailam.Jeerakam has garbhashaya shodhaka property according to Bhava mishra and hence Jeerakadyarishtam might have worked internally.Sukumaram kashayam is a liver stimulant. It might have worked in proper maintenance of jatharagni along with Chandraprabhavati which works efficiently on genito - urinary system. Yoni prakshalanam and yoni pichu are the local procedures that are highly effective in maintaining the local $\mathrm{pH}$ where Jatyadi tailam contains drugs that have vrana ropana and sodhana properties along with krimihara property.

\section{CONCLUSION}

From the observations and the results of the present case study, it can be concluded that the drugs that are having krimihara property along with garbhashaya sodhaka drugs may be working effectively on the antisperm antibodies.A regular and periodical treatment with triphala kashayam as yoni prakshalanam might have worked in cleansing the cervical mucus thereby reducing the rate of producing ASAB. Yoni pichu dharanam with Jatyadi tailam might have worked effectively in arresting the further growth of the antibodies in the cervical mucus. Both yoni prakshalanam and yoni pichu dharanam might have maintained the $\mathrm{pH}$ of the local area and further prevented the hostile nature of the cervical mucus towards the sperms and hence the serum ASAB also reduced significantly.

\section{REFERENCES}

1. Howkins and Bourne Shaw's Textbook of Gynaecology $-15^{\text {th }}$ edition-2013;published by ELSEVIER, A division of Reed Elsevier India Private Limited; page no:205\&210 
Dr Maganti Anuradha*, International Journal of Ayurvedic \& Herbal Medicine 8(3) May.-June. 2018 (3253-3255)

2. D.C.Dutta's Text book of Gynaecology $-6^{\text {th }}$ edition-2013;New Central Book Agency(P)Ltd, Kolkata; page no:229

3. Bhaishjya Ratnavali $-8^{\text {th }}$ edition-1987; Chaukhambha Sanskrit Samsthan, Varanasi; page no.597

4. Bhava prakasha nighantu- $10^{\text {th }}$ edition-1995;Chaukhambha Bharati Academy;page.no.30 